\title{
A Criança como Ator Social / The Child as a Social Actor
}

https://doi.org/10.21814/uminho.ed.36.5

\section{Yannis Pechtelidis}

University of Thessaly, Greece 



\section{A Criança Enquanto Ator Social}

Os desenvolvimentos recentes na sociologia e noutras ciências sociais deram uma contribuição decisiva para a concetualização da "criança" como ator social, capaz de moldar a sua identidade, produzir e comunicar visões confiáveis do mundo social, mantendo o direito de participar ativamente nele. A crença de que as crianças podem ser produtoras autónomas de significado, desafia as ideias tradicionais sobre o desenvolvimento infantil, que a apresentam como passiva, fraca e dependente, imatura e, portanto, incapaz de tomar decisões responsáveis sobre a sua vida. Tais abordagens de desenvolvimento infantil levaram à exclusão das crianças dos processos de tomada de decisão e da vida pública em geral. No polo oposto, está a representação da criança como ator social ativo, o que contribui para a sua inclusão em contextos sociais dos quais eram excluídas e não tinham direitos, até recentemente.

Uma nova perceção da "criança" como cidadão, como um cidadão detentor de direitos surgiu recentemente e afetou as relações entre adultos e crianças (Baraldi \& Cockburn, 2018). Esta noção foi desenvolvida com base na perceção da criança como sujeito ativo, bem como no argumento de que as crianças têm o direito de participar na esfera pública e, de forma mais geral, no contexto sociopolítico. Este argumento está de acordo com os princípios da Convenção sobre os Direitos da Criança, que garante o direito das crianças ao lazer, às atividades culturais, ao uso de sua própria cultura e língua, privacidade, proteção, autonomia e participação, etc.

Além disso, a contribuição da Sociologia da Infância e dos Estudos da Infância em geral para a discussão da participação das crianças na sociedade é fundamental porque nos ajudou a compreender melhor e em profundidade, não só a capacidade das crianças de participarem de diferentes processos sociais, mas, também, as formas como agem conscientemente através da sua participação em diferentes áreas da sociedade, o grau da sua participação, as condições em que participam na vida social, as consequências da sua participação, as experiências decorrentes da participação ou não participação, etc. (Perry-Smith \& Thomas, 2010). Possuímos, atualmente, literatura importante sobre as crianças como atores sociais e o seu envolvimento ativo na educação, vida familiar, economia, cultura, política e 
cidadania, bens comuns, que nos ajuda a compreender a natureza e a extensão da participação infantil na vida social e, consequentemente, os limites da independência e autonomia das crianças na modernidade tardia.

As crianças, com as suas intervenções e mobilizações públicas, como são exemplo as recentes sobre a proteção do meio ambiente e do planeta, aparecem ativas, críticas, complexas, com competências e habilidades sociais. Elas discutem os problemas que enfrentam na vida familiar, comunitária e escolar e, portanto, desafiam as narrativas ocidentais dominantes de que as crianças são seres sociais imaturos e irracionais, sem capacidade de pensar criticamente, etc.

No entanto, hoje em dia, uma nova imagem neoliberal de "criança" começa a emergir, a criança autónoma, capaz e flexível, que é independente, pode resolver problemas, responsável pelo seu caminho de aprendizagem através da autorreflexão. Essa criança tem um suposto desejo natural e capacidade para aprender e é encorajada a fazer perguntas, resolver problemas e buscar respostas. Assim, difere do modelo da criança em desenvolvimento natural da modernidade, uma vez que o objetivo já não é revelar a verdadeira substância da criança com o auxílio da psicologia do desenvolvimento. No entanto, esta imagem da "criança capaz" não nos deve levar a concluir que a governança está a diminuir, mas sim, que é outra forma de governança. Investir no futuro ainda é um objetivo importante dessa forma de governança infantil, como nas formas anteriores de governança, mas a diferença é que agora se oferece às crianças um papel ativo no desenvolvimento do seu próprio capital humano. 0 futuro é predominantemente determinado pelo mercado capitalista global, não pelas próprias crianças. A infância aparece como uma fase de transição e a ação das crianças tem limites pré-determinados pelo mercado. A transição das crianças para a idade adulta é pré-determinada pelos adultos e por planos políticos hegemónicos específicos para a construção de relações sociais. Importantes qualidades humanas, como inovação, responsabilidade, ativismo, são percebidas diretamente em relação às relações de troca do mercado empresarial capitalista. Nesse sentido, a criança como ator social é uma criança controlada e orientada, influenciada e moldada por estratégias neoliberais hegemónicas destinadas a desenvolver as habilidades infantis de autorregulação e autogestão (Smith, 2012).

É importante distinguir a imagem neoliberal apresentada acima da criança como ator e as imagens da criança produzidas no campo da Sociologia da Infância, porque num primeiro nível a impressão é que essas duas imagens 
convergem ideologicamente. Em suma, a nova Sociologia da Infância aumenta o estatuto das crianças através da promoção dinâmica da imagem das crianças como "atores sociais capazes" que participam da sociedade como indivíduos autónomos e cidadãos e cidadãos com direitos no "aqui e agora" em vez de futuros adultos. Também questiona, sistematicamente, o determinismo biológico da cultura popular e do pensamento científico. Além disso, a educação das crianças parece ser mais democrática, pois depende da comunicação e da resolução mútua de questões quotidianas.

\section{The Child as a Social Actor}

The recent developments in sociology, and other social sciences, have made a decisive and important contribution to the conceptualization of the "child" as a social actor capable of shaping his or her identity, producing and communicating reliable views of the social world, while retaining the right to participate actively in it. The belief that children can be autonomous producers of meaning challenges traditional ideas about child's development, which present the child as passive, weak, dependent, and immature, and therefore unable to make responsible decisions about his or her life. These childhood developmental approaches have led to the exclusion of children from the decision-making processes and public life in general. On the contrary, there is the representation of children as active social actors. This representation contributes to the inclusion of children in social settings from which they have been excluded and where they have not had rights until recently.

A new perception of the 'child' as a citizen, as a commoner and rights-holder, has emerged relatively recently and has affected relationships between adults and children (Baraldi \& Cockburn, 2018). This notion was developed on the basis of the perception of child as an active subject, as well as the argument that children have the right to participate in the public sphere and, more generally, in the socio-political context. This argument is in line with the principles of the Convention on the Rights of the Child. The Convention guarantees the right of children to leisure, cultural activities, the use of their own culture and language, privacy, protection, autonomy and participation, etc.

Moreover, the contribution of Sociology of Childhood and Childhood Studies in general to the discussion of children's participation in society is crucial, because it has helped us to understand better and in depth not only the 
ability of children to participate in different social processes, but also the ways in which they consciously act through their participation in different areas of society, the degree of their participation, the conditions under which they participate in social life, the consequences of their participation, the experiences which derive from participation or non-participation, etc. (Perry-Smith \& Thomas, 2010). Currently, there is important literature on children as social actors and on children's active involvement in education, family life, economy, culture, politics and citizenship, and shared assets. This literature now helps us to understand the nature and extent of child participation in social life and consequently, the limits of children's independence and autonomy.

Children, with their public interventions and protests, like the recent ones about the protection of the environment and the planet, seem active, critical, and complex, with social skills and abilities. They discuss the problems they face within their family, community and school life, and therefore challenge the dominant Western narratives that children are immature and irrational social beings, without the ability to think critically.

However, nowadays, a new neo - liberal image of "child" has begun to emerge, the autonomous, capable and flexible child, who is independent, can solve problems, and is responsible for his or her learning path through self-reflection. This child is supposed to have a natural desire and ability to learn and is encouraged to ask questions, solve problems, and seek answers. Therefore, it differs from the model of the naturally developing child of modern times, since the aim is no longer to reveal the child's true substance with the aid of developmental psychology. Yet, this image of the "capable child" should not lead us to conclude that governance is diminishing, but that it is another form of governance. Investing in the future is still an important objective of this form of child governance, as in previous forms of governance, but the difference is that children are now being offered an active role in developing their own human capital. The future is predominantly determined by the global capitalist market, not by the children themselves. Childhood appears as a transitional stage and children's actions have pre-determined limits imposed by the market. The transition of children to adulthood is pre-determined by adults and by specific hegemonic political plans for building social relationships. Important human qualities, such as innovation, responsibility, and activism, are perceived directly in relation to the exchange relations of the capitalist business market. In this sense, the child as a social actor is a controlled and guided child, influenced 
and shaped by hegemonic neo-liberal strategies designed to develop children's abilities for self-regulation and self-management (Smith, 2012).

It is important to distinguish the the above described neo liberal image of the child as an actor and the images of child produced within the field of sociology of childhood, because at one level, the impression is that those two images converge ideologically. In a nutshell, the new sociology of childhood enhances the status of children through the dynamic promotion of the image of children as "capable social actors" who participate in society as autonomous individuals and citizens with rights in "the here and the now" rather than as future adults. It also systematically questions the biological determinism of popular culture and scientific thinking. In addition, the upbringing and education of children appear more democratic as they rely on communication and mutual settlement of everyday issues.

\section{Referências / References}

Baraldi, C. \& Cockburn, T. (2018) (Eds.). Theorising Childhood: Citizenship, Rights, and Participation. London: Palgrave Macmillan.

Percy-Smith, B. \& Thomas, N. (2010) (Eds.). A Handbook of Children and Young People's Participation Perspectives from theory and practice. New York: Routledge.

Smith, K. (2012). Producing governable subjects: Images of childhood old and new. Childhood, 19(1), 24-37. 